\title{
ALTROMYCINS, NOVEL PLURAMYCIN-LIKE ANTIBIOTICS \\ I. TAXONOMY OF THE PRODUCING ORGANISM, FERMENTATION AND ANTIBACTERIAL ACTIVITY
}

\author{
Marianna Jackson, James P. Karwowski, Robert J. Theriault, \\ Dwight J. Hardy, Sue J. Swanson, Grant J. Barlow, \\ PaUline M. TIllis and JAMES B. McAlpine \\ Anti-infective Research Division, Abbott Laboratories, \\ Abbott Park, IL. 60064, U.S.A.
}

(Received for publication September 19, 1989)

\begin{abstract}
The altromycins are novel anthraquinone-derived antibiotics related to the pluramycins. They are produced by an actinomycete, AB 1246E-26, which was isolated from a South African bushveld soil. The altromycins have Gram-positive antibacterial activity with MICs of 0.2 to $3.12 \mu \mathrm{g} / \mathrm{ml}$ against Streptococci and Staphylococci.
\end{abstract}

The altromycins are a complex of novel anthraquinone-derived antibiotics found in the culture broth of an actinomycete designated strain AB $1246 \mathrm{E}-26$. They are structurally related to the pluramycins ${ }^{1)}$. This paper describes the discovery and fermentation of the altromycins, the taxonomy of the producing organism and the antibacterial properties of altromycin $\mathrm{B}$. The isolation and structure elucidation of the altromycins are reported in a companion paper ${ }^{2}$.

\section{Materials and Methods}

\section{Microorganisms}

Strain AB 1246E-26 was isolated from a soil collected from a South African bushveld. The isolation procedure was intended to enrich for nocardioform actinomycetes. The soil was suspended in water and heated to $55^{\circ} \mathrm{C}$ for 5 minutes. Dilutions of the heated suspension were plated on a dilute nutrient medium consisting of Tryptone $0.15 \%$, peptone $0.025 \%, \mathrm{NaCl} 0.025 \%$, glucose monohydrate $0.05 \%$ and agar $1.5 \%$. This medium was amended with cycloheximide $(50 \mu \mathrm{g} / \mathrm{ml})$, nystatin $(20 \mu \mathrm{g} / \mathrm{ml})$, nalidixic acid $(30 \mu \mathrm{g} / \mathrm{ml})$ and novobiocin $(20 \mu \mathrm{g} / \mathrm{ml})$. The plates were incubated for 21 days at $30^{\circ} \mathrm{C}$. Pseudomonas aeruginosa $\mathrm{K} 799 / 61$ was obtained from ZIMMERMANN ${ }^{3)}$. Other strains were from the American Type Culture Collection (ATCC) or from the stock culture collection in our laboratory.

\section{Discovery Screen}

The altromycins were found by a two stage screen for substances with activity against $P$. aeruginosa which we described previously for the discovery of the coumamidines ${ }^{4}$. Essentially, strain AB $1246 \mathrm{E}-26$ was selected because plugs of the culture grown on agar had activity against K799/61, a highly antibiotic-sensitive strain of $P$. aeruginosa.

\section{Taxonomic Studies}

Methods and media described by the International Streptomyces Project (ISP) ${ }^{5)}$, WAKSMAN ${ }^{6)}$ and GoRDON et al. ${ }^{7}$ were used to determine most of the morphological and physiological characteristics. ATCC medium $172^{\dagger}$ and modified Gause No. 1 agar were also employed for the cultural characteristics. Color

+ American Type Culture Collection. ATCC Media Handbook. First Ed. American Type Culture Collection, Rockville, 1984. 
names were assigned to the mycelial and diffusible pigments on the basis of the Inter-Society Color Council-National Bureau of Standards (ISCC-NBS) Color-Name Charts. With the exception of the temperature study, incubation was at $28^{\circ} \mathrm{C}$. The diaminopimelic acid isomer was determined by the method of BECKER et al. ${ }^{8}$. Whole cell sugars were characterized by the procedure of LECHEVALIER ${ }^{9}$. Menaquinones were extracted as described by ATHALYE et al. ${ }^{10)}$ and analyzed by mass spectroscopy.

Fermentation

The seed medium consisted of glucose monohydrate $1.0 \%$, Staclipse JUB starch (Staley) $1.5 \%$, yeast extract (Difco) $0.5 \%, \mathrm{NZ}$ amine type A (Humko Sheffield) $0.5 \%$ and $\mathrm{CaCO}_{3} 0.1 \%$. The pH was adjusted to 7.0 before sterilization. Inoculum for fermentations was maintained as frozen $\left(-75^{\circ} \mathrm{C}\right)$ vegetative mycelium. It was used at $0.7 \%$ to inoculate $25 \times 150 \mathrm{~mm}$ tubes containing $10 \mathrm{ml}$ of the seed medium, which were incubated for 96 hours at $28^{\circ} \mathrm{C}$. Vegetative growth from the seed tubes was transferred at $5 \%$ to 2 -liter Erlenmeyer flasks containing $600 \mathrm{ml}$ of the seed medium. The flasks were incubated for 72 hours at $28^{\circ} \mathrm{C}$. For production of the antibiotic, a 150 -liter New Brunswick fermenter was charged with 80 liters of a medium consisting of glucose monohydrate $2 \%$, Lexein F-152 liquid peptone (Inolex) $1 \%$, molasses (Del Monte) $0.5 \%$, yeast extract (Difco) $0.1 \%$ and $\mathrm{CaCO}_{3} 0.2 \%$. The medium was prepared in distilled water and the $\mathrm{pH}$ was not adjusted. Sterilization was at $121^{\circ} \mathrm{C}$ and $1.05 \mathrm{~kg} / \mathrm{cm}^{2}$ for 1 hour. The fermentation was carried out at $28^{\circ} \mathrm{C}$ for 162 hours. The agitation was $200 \mathrm{rpm}$, the aeration was $0.7 \mathrm{v} / \mathrm{v} / \mathrm{m}$ and the head pressure was $0.35 \mathrm{~kg} / \mathrm{cm}^{2}$.

\section{Fermentation Analyses}

Cell growth was evaluated as packed cell volume by centrifuging the fermentation broth in a graduated conical tube at $600 \times g$ for 20 minutes. Reducing sugar was determined by the dinitrosalicylic acid method described by BERNFELD ${ }^{11)}$. An agar diffusion assay using Staphylococcus aureus ATCC 6538P in streptomycin assay agar with yeast extract $(\mathrm{BBL})$ was performed to monitor the accumulation of antibiotic during the fermentation.

\section{In Vitro Activity}

The MICs for altromycin B were determined by a 2-fold agar dilution method ${ }^{\dagger}$ in brain heart infusion agar.

\section{Results}

Discovery

The altromycin producing culture was selected from other soil isolates for its activity against $P$. aeruginosa K799/61. Concentrates of the fermentation broth were sufficiently active against other Pseudomonas strains to sustain interest in the antibiotic, and the isolation of the active components was accomplished using $P$. aeruginosa $\mathrm{BMH} 10$ as the indicator.

\section{Taxonomy}

The vegetative mycelium of $\mathrm{AB} 1246 \mathrm{E}-26$ is branched and has a tendency to fragment. Spores have not been observed. The appearance of strain AB $1246 \mathrm{E}-26$ on eleven media is given in Table 1. Aerial mycelium is formed on yeast extract - malt extract, tyrosine and peptone - yeast extract - iron agars but only sparsely on other media. Soluble pigments are formed on media containing peptones and amino acids. The ability of this strain to utilize various carbohydrates and polyols as the sole source of carbon in synthetic medium is shown in Table 2. Some physiological properties are given in Table 3.

meso-Diaminopimelic acid, arabinose and galactose were found in whole-cell hydrolysates indicating

+ National Committee for Clinical Laboratory Standards. Methods for dilution antimicrobial susceptibility tests for bacteria that grow aerobically. Approved standard M7-A. National Committee for Clinical Laboratory Standards, Villanova, 1985. 
Table 1. Cultural characteristics of strain AB 1246E-26.

\begin{tabular}{|c|c|}
\hline Medium & Cultural characteristics \\
\hline \multirow[t]{4}{*}{ Yeast extract - malt extract agar (ISP 2) } & G: Abundant \\
\hline & AM: White to light gray $(264)^{\mathrm{a}}$ \\
\hline & $\mathrm{R}$ : Moderate reddish brown (43) \\
\hline & SP: Moderate brown $(58)$ \\
\hline \multirow[t]{4}{*}{ Oatmeal agar (ISP 3) } & G: Moderate \\
\hline & AM: Sparse, white \\
\hline & R: Yellowish gray (93) \\
\hline & SP: Absent \\
\hline \multirow[t]{3}{*}{ Inorganic salts - starch agar (ISP 4) } & G: Poor \\
\hline & AM: Sparse, white \\
\hline & SP: Absent \\
\hline \multirow[t]{3}{*}{ Glycerol - asparagine agar (ISP 5) } & G: Abundant \\
\hline & AM: Sparse, white \\
\hline & $\begin{array}{l}\text { R: Grayish reddish orange (39); moderate orange } \\
\text { (53); grayish yellow (90) }\end{array}$ \\
\hline · & SP: Light grayish reddish brown (45) \\
\hline \multirow[t]{4}{*}{ Peptone - yeast extract - iron agar (ISP 6) } & $\mathrm{G}:$ Moderate \\
\hline & AM: White \\
\hline & R: Grayish reddish orange (39) \\
\hline & SP: Light reddish brown (42) \\
\hline \multirow[t]{4}{*}{ Tyrosine agar (ISP 7) } & G: Abundant \\
\hline & AM: Yellowish white (92) \\
\hline & R: Moderate reddish brown (43) \\
\hline & SP: Grayish reddish brown (46) \\
\hline \multirow[t]{4}{*}{ Nutrient agar } & G: Moderate \\
\hline & AM: Sparse, white \\
\hline & R: Light orange (52) \\
\hline & SP: Light grayish reddish brown (45) \\
\hline \multirow[t]{4}{*}{ CZAPEK's agar } & G: Moderate \\
\hline & AM: Sparse, white \\
\hline & R: Yellowish gray (93) \\
\hline & SP: Absent \\
\hline \multirow[t]{3}{*}{ Calcium malate agar } & G: Poor \\
\hline & AM: Sparse, white \\
\hline & SP: Absent \\
\hline \multirow[t]{4}{*}{ ATCC No. 172} & G: Moderate \\
\hline & AM: Sparse, light gray (264) \\
\hline & R: Grayish reddish orange (39) \\
\hline & SP: Absent \\
\hline \multirow[t]{4}{*}{ Gause No. 1 modified $^{\text {b }}$} & G: Moderate \\
\hline & AM: Sparse, white \\
\hline & R: Light gray (264) \\
\hline & SP: Absent \\
\hline
\end{tabular}

a Color names and number in parentheses follow the color standard in KELLY, K. L. and D. B. JUDD: ISCC-NBS Color-Name Charts Illustrated with Centroid Colors. U.S. Dept. of Comm. Suppl. to Cir. 553, Washington, D.C., 1976

b $\mathrm{KNO}_{3} 0.1 \%, \mathrm{~K}_{2} \mathrm{HPO}_{4} 0.05 \%, \mathrm{MgSO}_{4} 0.05 \%, \mathrm{NaCl} 0.05 \%, \mathrm{FeSO}_{4} 0.001 \%$, starch $0.1 \%$, yeast extract $0.01 \%$ and agar $1.5 \%$.

Observations after incubation for 14 days at $28^{\circ} \mathrm{C}$.

G: Growth, AM: aerial mycelium, R: reverse, SP: soluble pigment.

a cell wall of type IVA ${ }^{12)}$. The major menaquinone has MW 720 by MS and is, therefore, tetrahydrogenated with 8 isoprenoid units.

\section{Fermentation}

Growth, $\mathrm{pH}$, consumption of carbohydrate and accumulation of altromycins are plotted in a time 
Table 2. Utilization of various compounds as the sole source of carbon ${ }^{51}$ by strain AB $1246 \mathrm{E}-26$.

\begin{tabular}{|c|c|c|c|}
\hline Carbon sources & Growth & Carbon sources & Growth \\
\hline Adonitol & - & Mannose & ++ \\
\hline Arabinose & $+t$ & Melezitose & - \\
\hline Cellulose & - & Melibiose & - \\
\hline Dulcitol & - & Raffinose & - \\
\hline Fructose & ++ & Rhamnose & + \\
\hline Galactose & ++ & Ribose & ++ \\
\hline Glucose & ++ & Salicin & + \\
\hline Inositol & $+t$ & Sorbitol & + \\
\hline Inulin & - & Starch & - \\
\hline Lactose & - & Sucrose & - \\
\hline Maltose & - & Trehalose & ++ \\
\hline Mannitol & ++ & Xylose & + \\
\hline
\end{tabular}

Incubation was at $28^{\circ} \mathrm{C}$ for 30 days.

++ : Good utilization, + : poor utilization, - : did not utilize.

Table 3. Physiological characteristics of strain AB 1246E-26.

\begin{tabular}{|c|c|c|c|}
\hline Test & Reaction & Test & Reaction \\
\hline Starch hydrolysis & - & Casein & + \\
\hline $\mathrm{H}_{2} \mathrm{~S}$ production & + & Xanthine & - \\
\hline Melanin formation & & Hypoxanthine & + \\
\hline Peptone - yeast extract - iron agar & - & Resistance to lysozyme & + \\
\hline Tyrosine agar & - & Resistance to antibiotics $(50 \mu \mathrm{g} / \mathrm{ml})$ & \\
\hline \multirow[t]{2}{*}{$\mathrm{NaCl}$ tolerance } & Growth at $4 \%$ & Erythromycin & + \\
\hline & but not at $7 \%$ & Gentamicin & - \\
\hline \multirow[t]{3}{*}{ Temperature range } & Growth at 21 & Kanamycin & + \\
\hline & to $42^{\circ} \mathrm{C}$ & Novobiocin & + \\
\hline & No growth at $54^{\circ} \mathrm{C}$ & Oxytetracycline & \pm \\
\hline Litmus milk & Alkaline digestion & Rifampicin & $\bar{t}$ \\
\hline Decomposition of: & & Streptomycin & + \\
\hline Adenine & + & Vancomycin & + \\
\hline
\end{tabular}

Table 4. Antibacterial activity of altromycin B.

\begin{tabular}{|c|c|c|c|}
\hline Organism & $\begin{array}{c}\text { MIC } \\
(\mu \mathrm{g} / \mathrm{ml})\end{array}$ & Organism & $\begin{array}{c}\text { MIC } \\
(\mu \mathrm{g} / \mathrm{ml})\end{array}$ \\
\hline Staphylococcus aureus ATCC 6538P & 0.39 & S. pyogenes 2548 & 0.39 \\
\hline S. aureus CMX 686B & 1.56 & Escherichia coli Juhl & $>100$ \\
\hline S. aureus A5177 & 1.56 & E. coli $\mathrm{SS}$ & 0.2 \\
\hline S. aureus 45 & 0.39 & E. coli $\mathrm{DC}-2$ & $>100$ \\
\hline S. aureus 45 RAR2 & 3.12 & E. coli $\mathrm{H} 560$ & $>100$ \\
\hline S. aureus CMX 503A & 1.56 & E. coli KNK 437 & 25 \\
\hline S. aureus CMX 553 & 3.12 & Enterobacter aerogenes ATCC 13048 & $>100$ \\
\hline S. epidermidis 3519 & 1.56 & Klebsiella pneumoniae ATCC 8045 & $>100$ \\
\hline Micrococcus luteus ATCC 9341 & 0.1 & Providencia stuartii CMX 640 & $>100$ \\
\hline M. luteus ATCC 4698 & 0.39 & Pseudomonas aeruginosa $\mathrm{BMH} 10$ & 50 \\
\hline Enterococcus hirae ATCC 8043 & 3.12 & P. aeruginosa A5007 & $>100$ \\
\hline Streptococcus bovis A5169 & 3.12 & P. aeruginosa $\mathrm{K} 799 / \mathrm{WT}$ & 3.12 \\
\hline S. agalactiae CMX 508 & 0.39 & P. aeruginosa $\mathrm{K} 799 / 61$ & 0.1 \\
\hline S. pyogenes EES61 & 0.39 & P. cepacia 2961 & $>100$ \\
\hline S. pyogenes 930 & 0.2 & Acinetobacter sp. CMX 669 & $>100$ \\
\hline
\end{tabular}


course study of a fermentation with strain $\mathrm{AB}$ 1246E-26 (Fig. 1). A maximum potency of $112 \mu \mathrm{g} / \mathrm{ml}$ was achieved in 114 hours.

\section{Antibacterial Activity}

The MICs of altromycin B are given in Table 4. MICs for clinical isolates of Staphylococci range from 0.39 to $3.12 \mu \mathrm{g} / \mathrm{ml}$. MICs for Streptococci are 0.2 to $3.12 \mu \mathrm{g} / \mathrm{ml}$. With the exception of strains with compromised outer membranes, the MICs for Gram-negative bacteria are 25 to $>100 \mu \mathrm{g} / \mathrm{ml}$.

\section{Discussion}

The altromycin-producing strain is an actinomycete with a cell-wall of type IVA as expected by the soil isolation technique. The lack of sporulation and any remarkable morphological features requires that the identification of this culture rely on chemotaxonomy. The accumulated data narrow the taxonomic assignment of this culture to Nocardia or one of the genera grouped as Micropolysporas ${ }^{13}$. More extensive lipid analysis is needed to definitively assign this strain to a specific genus. The culture has been deposited at the Northern Regional Research Center in Peoria, Illinois, U.S.A., where it was assigned the accession No. NRRL 18371.

Although the altromycins were originally selected and isolated for their activity against a sensitive strain of Pseudomonas, their antibacterial activity is restricted to Gram-positive organisms. The MICs for Streptococci and Staphylococci suggest that the altromycins may have clinical utility.

\section{Acknowledgment}

The authors wish to thank Dr. A. M. Buko for mass spectral measurements.

\section{References}

1) Kondo, S.; M. Miyamoto, H. Naganawa, T. Takeuchi \& H. Umezawa: Structures of pluramycin A and neopluramycin. J. Antibiotics 30: 1143 1145, 1977

2) Brill, G. M.; J. B. MCAlpine, D. N. Whittern \& A. M. Buko: Altromycins, novel pluramycin-like antibiotics. II. Isolation and elucidation of structure. J. Antibiotics 43: 229 237, 1990

3) ZimmermanN, W.: Penetration through the gram-negative cell wall: a co-determinant of the efficacy of beta-lactam antibiotics. Int. J. Clin. Pharmacol. Biopharm. 17: 131 134, 1979

4) Jackson, M.; J. P. Karwowski, R. J. Theriault, W. L. Kohl, P. E. Humphrey, G. N. Sunga, S. J. Swanson \& R. M. VillaRREAL: Coumamidines, new broad spectrum antibiotics of the cinodine type. I. Discovery, taxonomy of the producing organism and fermentation. J. Antibiotics 42: 527 532, 1989

5) Shirling, E. B. \& D. Gottlieb: Methods for characterization of Streptomyces species. Int. J. Syst. Bacteriol. 16: $313 \sim 340,1966$

6) Waksman, S. A. $(E d$.): The Actinomycetes. Vol. 2. Classification, Identification and Descriptions of Genera and Species. Williams \& Wilkins Co., 1961

7) Gordon, R. E.; D. A. Barnett, J. E. Handerhan \& C. H.-N. Pang: Nocardia coeliaca, Nocardia autotrophica, and the nocardin strain. Int. J. Syst. Bacteriol. 24: 54 63, 1974

8) Becker, B.; M. P. LecheVAlier, R. E. Gordon \& H. A. LecheVAliER: Rapid differentiation between Nocardia and Streptomyces by paper chromatography of whole-cell hydrolysates. Appl. Microbiol. 12: 421 423, 1964 
9) LeCHEVAliER, M. P.: Identification of aerobic actinomycetes of clinical importance. J. Lab. Clin. Med. 71: 934 944, 1968

10) Athalye, M.; M. Goodfellow \& D. E. Minnikin: Menaquinone composition in the classification of Actinomadura and related taxa. J. Gen. Microbiol. 130: $817 \sim 823,1984$

11) Bernfeld, P.: Amylases, $\alpha \& \beta$. In Methods in Enzymology, Vol. I. Eds. S. P. Colowick \& N. O. KaPlan, pp. $149 \sim 158$, Academic Press, 1955

12) Lechevalier, M: P. \& H. A. Lechevalier: Chemical composition as a criterion in the classification of aerobic actinomycetes. Int. J. Syst. Bacteriol. 20: 435 443, 1970

13) Goodfellow, M. \& T. Cross: Classification. In The Biology of the Actinomycetes. Ed., M. Goodfellow et al., pp. $7 \sim 164$, Academic Press, 1984 